\title{
The development of tree species composition of the species-rich natural forest during the last 33 years
}

\author{
M. Balanda ${ }^{1}$, M. Saniga ${ }^{1}$, J. Pittner ${ }^{1}$
}

${ }^{1}$ Technical University in Zvolen, Department of Silviculture, Faculty of Forestry, T. G. Masaryka 24, 96053 Zvolen, Slovak republic.E-mail:miroslav.balanda@tuzvo.sk

Abstract: Balanda, M., Saniga M., Pittner J. 2013: The development of tree species composition of the species-rich natural forest during the last 33 years. - Beskydy, 6 (1): 9-16

The presented study is aimed on the analysis of inventory data from the old-growth mixed forest of National Nature Reserve (NNR) Sitno. A special attention was paid to the temporal variation of the tree species composition. Study analyzes data acquired in the decadal periodic inventory campaigns during the last 33 years. Analysis of dynamic changes in portion of partial tree species in NNR Sitno revealed the significant continuous decrease of oak trees during analyzed period. Evaluation of temporal changes showed the significant decrease of oaks regarding the number of trees thicker than $8 \mathrm{~cm}(8 \%)$ as well as the volume of large wood (11\%). On the other hand, the European beech is achieving the dominant position within the upper tree layer on the behalf of oaks and other tree species. Inventory revealed slight decrease of beech in term number of tree individuals that is connected with significant increase of the large wood volume. We recorded the increasing abundance of maples (Acer pseudoplatanus, Acerplatanoides) and common ash in the natural regeneration.

Keywords: natural forest, oak decline, NNR Sitno, stand structure, inventory

\section{Introduction}

Natural forests, their dynamics, structure and texture is of a great importance for the formulation of the principles and guidelines of closeto-nature silviculture (Brang 2005, Leibundgut 1993, Meyer 2005, Parviainen 2005, Schütz 2002).

In the temperate zone of Europe, the oldgrowth oak forest remnants cover only a minimal area from these the ecosystems with pedunculate oak (Quercus robur L.) are prevailing (Korpel' 1995, Parviainen et al. 1999, Smejkal et al. 1995).

Natural mixed sessile oak (Quercus petraea (Matt.) Liebl.) forests remained untouched only on a very small area due to their easy accessibility and their intensive use in the past (Kavuljak 1942, Korpel' 1995, Smejkal et al. 1995). Larger reserves could be found in the Carpathian Arc in Slovakia (Korpel' 1995) and in Romania (Smejkal et al. 1995). Smaller areas are located also in Slovenia (Diaci et al. 2008), Austria (Rahman et al. 2008, Vacik et al. 2009), Czech Republic (Vrška et al. 2006) and Poland (Bobiec 2007). The structure of natural mixed forests with pedunculate oak in north and central Portugal was studied by Carvalho (2011).

The remnants of old-growth mixed Q. petraea forests are naturally distributed at the intermediate and lower altitudes of the Western Carpathians (Lukáčik et al. 2012, Lukáčik, Ďuriš 2012, Blattný, Štastný 1959). These are the last objects, where the structure and the alternation of tree species within their developmental cycle can be studied (Korpel' 1995, Korpel', Saniga 1995). In the old-growth Q. petraea forests of the Carpathian Arc, the typical two-layered structure prevails. Upper tree layer is dominated by sessile oak (Q.petraea), in some ecosystems with an admixture of Turkey oak (Quercus cerris L.), 
while the middle tree layer is formed by European beech (Fagus sylvatica L.), silver fir (Abies alba Mill.), European hornbeam (Carpinus betulus L.), lime (Tilia spp.), sycamore maple (Acer pseudoplatanus L.) and field maple (Acercampestre L.) (Korpel' 1995, Smejkal et al. 1995). The structure of these old-growth forests and its changes during the developmental cycle were extensively studied by Korpel' (1995). According to his results, duration of the developmental cycle in these forests usually does not exceed 300 years. The research was focused on the structure, regeneration processes and deadwood quantification in particular developmental stages of the old-growth forest. The observations were regularly conducted in the series of 0.5 ha permanent research plots, that represented the respective developmental stage.

The aim of this study is the analysis of inventory data from the old-growth mixed forest NNR Sitno during the last 33 years. The focus is oriented to changes of stand production parameters (basal area, volume of large wood) in the old-growth forest over 33 years with special emphasis on the temporal variation in the tree species composition.

\section{Material and methods}

National Nature Reserve Sitno belongs to the Central Slovakia region, Štiavnické Mts. $\left(48^{\circ} 24^{\prime}\right.$ 08.36" S, $18^{\circ} 52^{\prime} 35.04^{\prime \prime}$ V). The geological bedrock is composed by andesite, the prevailing soil type is cambisol. Natural forest remnant is located on the south facing slope in the altitude of 750-1010 $\mathrm{m}$ a.s.l. NNR belongs to the $3^{\text {rd }}$ vegetation zone, prevailing group of forest types Querceto-Fagetum with scattered occurrence of Querceto-Fagetum tiliosum and Tilieto-Aceretum (Zlatník 1956). Average annual temperature is $6{ }^{\circ} \mathrm{C}$, the mean annual precipitation amouts to $850 \mathrm{~mm}$.

The terrain data collection was carried out on the permanent research plots (PRP). Three different plots representing individual developmental stage of investigated natural forest> PRP I - breakdown stage, PRP II - optimum stage and PRP III - growth stage. The dimensions of each PRP were $70 \times 71.4 \mathrm{~m}, 0.5$ ha of each. The plot represents a basic unit for subsequent detailed inventory. Decadal periodic measurements were performed by research staff of the Dept. of Silviculture in years 1978, 1988, 1998 and 2011.

For each tree the following characteristics were determined (tree species, $d b h$, height $(h)$, crown base height $\left(h_{c b}\right)$, and horizontal projection of the crown $\left.\left(x_{1-i}\right)\right)$.
The upper tree height $\left(h_{0}\right)$ calculated according to Šmelko (2000) was used to divide the stand profile as follows: lower layer (trees up to $1 / 3$ of $\left.h_{0}\right)$, middle layer $\left(1 / 3-2 / 3 h_{0}\right)$, upper layer (tree height over $2 / 3 h_{0}$ ).

Detailed evidence of regeneration processes was conducted on each PRP. There the tree species and vertical height of plant individual were recorded. Natural regeneration was classified according to Korpel' (1995). We used the Prodan's formula (Prodan 1951) for the construction of height curves.

\section{Results}

From point of view of the tree species composition, the NNR represents the second richest natural forest after the NNR Hrončecký grún. The relation between two growth parameters (DBH and tree height) was expressed by Prodan's growth function (Fig. 1). The highest values of tree height within the spatial structure of natural forest were reached by maples, ash and beech. Growth of sessile oak and hornbeam is characterized by significantly lower values. The highest correlation coefficient and coefficient of determination were observed for beech $\mathrm{R}^{2}=0.89$ what represents significantly tight relationship. Presented relation could be explained by high tolerance of beech to variable light conditions within the frame of the production space of natural forest.

Beech is able to successfully tolerate such ecological profile and the changed ecological conditions do not influence its growth activity. Regarding other tree species, the calculated coefficients of determination were significantly lower. The lowest values were obtained for oak $\left(\mathrm{R}^{2}=0.59\right)$ and hornbeam $\left(\mathrm{R}^{2}=0.55\right)$. These results suggest that trees of thinner diameter are more overshadowed than thicker individuals. Considering the light requirements of this tree species, the height growth of individuals in position of lower and middle layer is more variable, determined by individual reaction of trees on the incoming light. For the purpose of growth analysis the data of Norway maple and sycamore were merged.

When comparing with oak and hornbeam results, the calculated coefficient of determination $\left(R^{2}=0.72\right)$ was higher by $13-17 \%$. Quoted results are confirming the fact that the higher tolerance to overshadowing will increase the tightness of analyzed relationship.

Analysis of temporal changes in numbers of trees thicker than $8 \mathrm{~cm}$ since 1978 till present showed the significant decrease of $8 \%$ and $9 \%$ in 


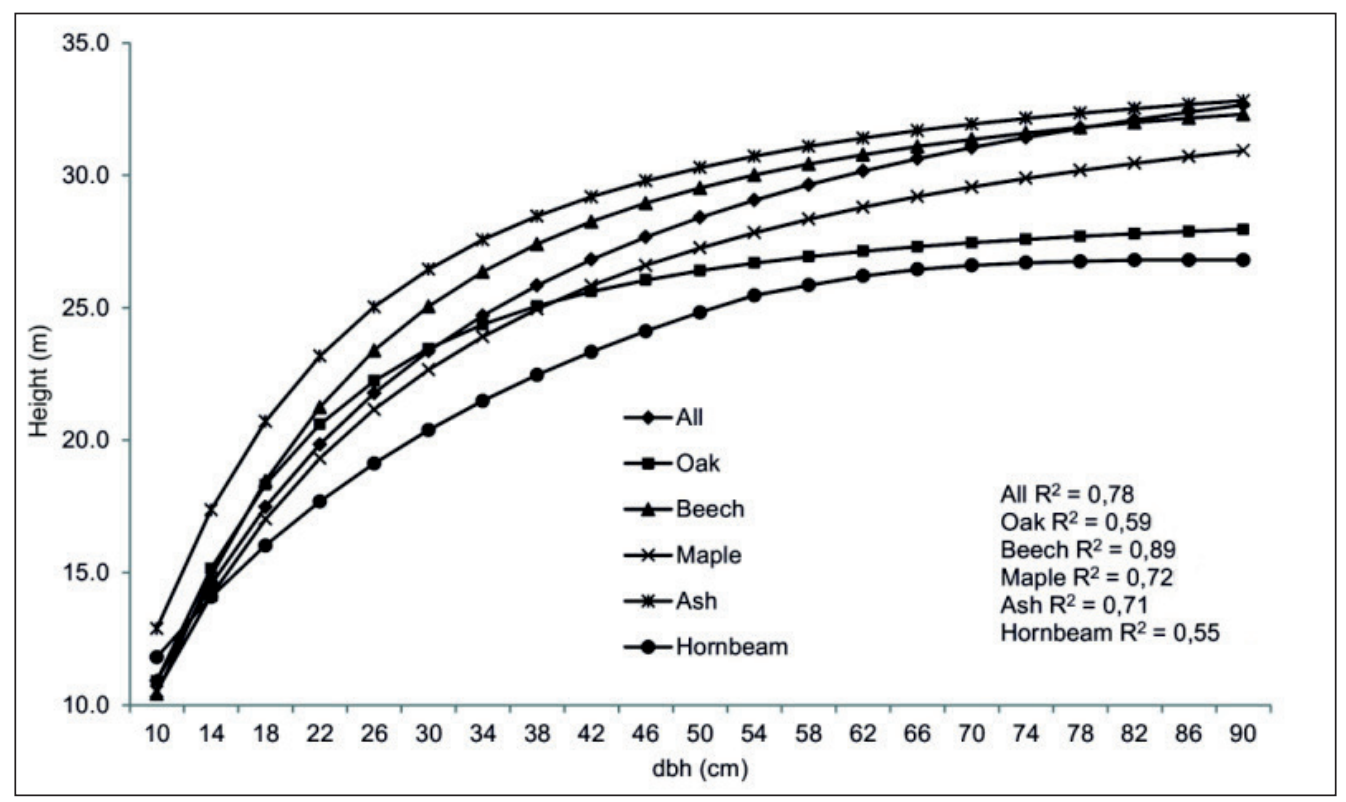

Fig. 1: Stand height curves of individual tree species, NNR Sitno (calculated according to Prodan (1951).

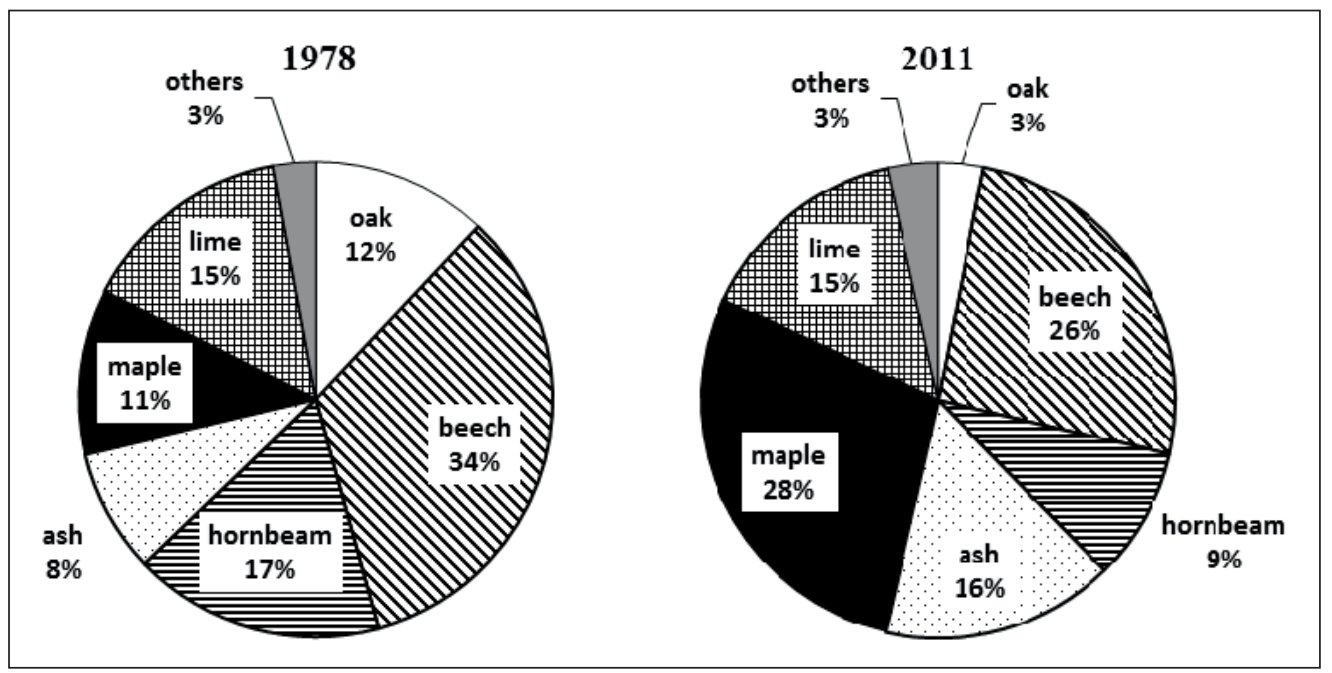

Fig. 2: Stand composition expressed by number of trees ( $d b h \geq 8 \mathrm{~cm}$ ) at the beginning (left) and at the end (right) of the inventory period.

proportion of beech and oak trees respectively (Fig. 2). In 1978, the portion of mentioned tree species that created the skeleton of stand structure was $48 \%$, and consequently their share has decreased on the level of $29 \%$ (until 2011). The portion of hornbeam has decreased from the value of $17 \%$ to $9 \%$ during the last three decades while the share of lime tree (Tilia sp.) remains constant during the investigated period. The significant increase in proportion of sycamore maple and Norway maple (by 17\%) as well as the European ash (by 8\%) was recorded in 2011.

The evaluation of basal area patterns (Fig. 3) shows the different tendency of structural development. The decrease of oak portion by $11 \%$ has been followed by increase of beech share from $31 \%$ to $37 \%$ of the total basal area. We observed slighter decrease for the hornbeam (4\%). Similar situation can be stated for maples (5\%) and the ash (4\%). 


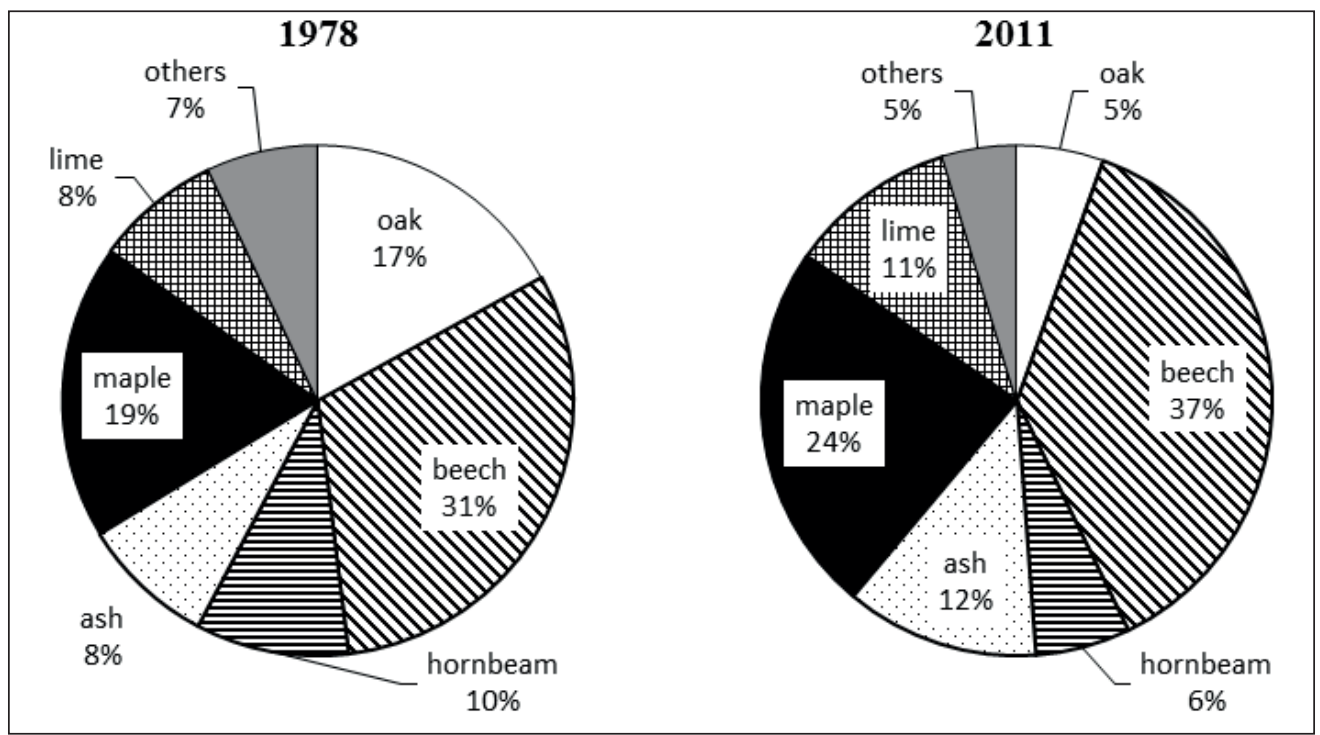

Fig. 3: Stand composition expressed by basal area of tree species (dbh $\geq 8 \mathrm{~cm})$ at the beginning (left) and at the end (right) of the inventory period.

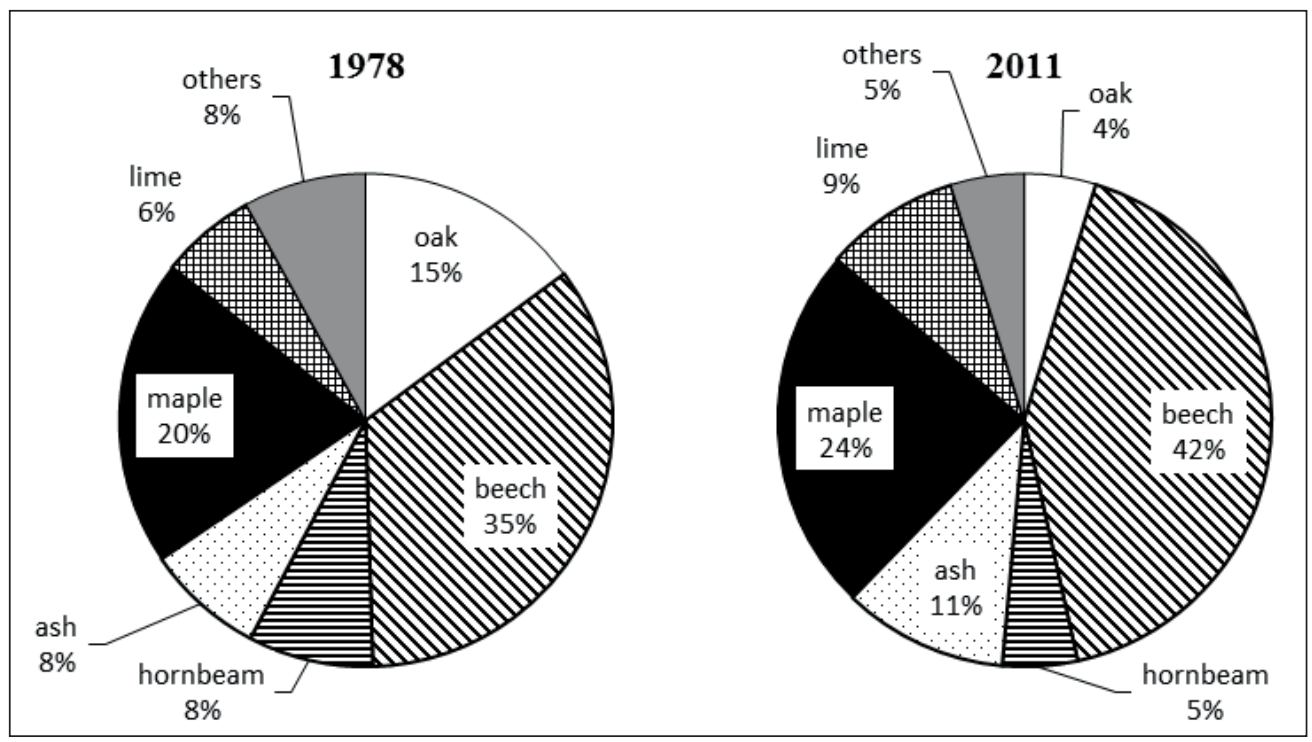

Fig. 4: Stand composition expressed by volume of merchantable wood of tree species (dbh $\geq 8 \mathrm{~cm}$ ) at the beginning (left) and at the end (right) of the inventory period.

The analysis of the structural changes of large wood volume of trees confirmed the similar tendency as stated above. The volume of oak has decreased by $11 \%$, the hornbeam showed the slight reduction by $3 \%$. The increase of beech is characterized by value of $7 \%$, maple $4 \%$ and ash $3 \%$ (Fig. 4). In spite of recorded reduction of the number of beech individuals, its increase in term of basal area and volume of large wood refers to the dominant position of beech within the upper tree layer with an intensive radial increment.

Similar situation appears in the position of maples and ash that were located in the upper tree layer. In general, we recorded continual decrease of oak from the tree species composition of natural forest during time span of 33 years. 
Tab. 1: Basic stand parameters according to years of inventory. Relative portion of oak is listed in separate columns.

\begin{tabular}{|c|c|c|c|c|c|c|c|c|c|}
\hline \multirow[t]{2}{*}{ Inventory } & \multicolumn{3}{|c|}{ Stand denstity (N.ha-1) } & \multicolumn{3}{|c|}{ Basal area $\left(\mathrm{m}^{2} \cdot \mathrm{ha}^{-1}\right)$} & \multicolumn{3}{|c|}{$\begin{array}{c}\text { Merchantable wood volume } \\
\left(\mathrm{m}^{3} \cdot \mathrm{ha}^{-1}\right)\end{array}$} \\
\hline & Total & Oak & \% Oak & Total & Oak & \% Oak & Total & Oak & \% Oak \\
\hline 1978 & 694 & 83 & 12.0 & 41.2 & 7.0 & 17.0 & 464.2 & 69.2 & 14.9 \\
\hline 1988 & 564 & 59 & 10.5 & 39.4 & 5.7 & 14.5 & 460.2 & 57.8 & 12.6 \\
\hline 1998 & 417 & 36 & 8.6 & 35.8 & 3.6 & 10.1 & 455.3 & 40.5 & 8.9 \\
\hline 2011 & 566 & 17 & 3.0 & 38.0 & 2.1 & 5.5 & 471.7 & 22.1 & 4.7 \\
\hline $\begin{array}{l}\text { Average } \\
\pm \text { SD }\end{array}$ & $560 \pm 113$ & $49 \pm 29$ & $9.0 \pm 3.9$ & $38.6 \pm 2.3$ & $46 \pm 2, .2$ & $11.8 \pm 5.0$ & $462.9 \pm 6.9$ & $47.4 \pm 20.6$ & $10.3 \pm 4.5$ \\
\hline
\end{tabular}

Tab. 2: Representation of natural regeneration according to tree species and year of measurement in NNR Sitno.

\begin{tabular}{|c|c|c|c|c|c|c|c|c|c|c|}
\hline Year 1978 & $\begin{array}{c}\text { Norway } \\
\text { maple }\end{array}$ & $\begin{array}{c}\text { Sycamore } \\
\text { maple }\end{array}$ & Ash & Oak & Lime & Beech & Hornbeam & Others & Total & $\%$ \\
\hline$<20 \mathrm{~cm}$ & 1917 & 844 & 161 & 11 & 11 & 161 & - & 6 & 3111 & 89.7 \\
\hline $21-50$ & 111 & 22 & 156 & 6 & & 33 & - & - & 328 & 9.5 \\
\hline $51-80$ & - & - & - & - & 28 & - & - & - & 28 & 0.8 \\
\hline $81-130$ & - & - & - & - & - & - & - & - & - & - \\
\hline$>131$ & - & - & - & - & - & - & - & - & - & - \\
\hline Total & 2028 & 867 & 317 & 17 & 39 & 194 & - & 6 & 3467 & 100.0 \\
\hline$\%$ & 58.5 & 25.0 & 9.1 & 0.5 & 1.1 & 5.6 & - & 0.2 & 100.0 & \\
\hline \multicolumn{11}{|l|}{ Year 2011} \\
\hline$<20 \mathrm{~cm}$ & 6556 & 6611 & 7000 & 56 & 56 & 1333 & 0 & - & 21611 & 44.0 \\
\hline $21-50$ & 4444 & 4944 & 3000 & 111 & 111 & 389 & 333 & - & 13333 & 27.1 \\
\hline $51-80$ & 3389 & 3389 & 1278 & 56 & 222 & 167 & 222 & - & 8722 & 17.8 \\
\hline 81-130 & 2167 & 889 & 556 & - & 111 & - & 111 & 56 & 3889 & 7.9 \\
\hline$>131 \mathrm{~cm}$ & 778 & 222 & 500 & - & - & - & 56 & - & 1556 & 3.2 \\
\hline Total & 17333 & 16056 & 12333 & 222 & 500 & 1889 & 722 & 56 & 49111 & 100.0 \\
\hline$\%$ & 35.3 & 32.7 & 25.1 & 0.5 & 1.0 & 3.8 & 1.5 & 0.1 & 100.0 & \\
\hline
\end{tabular}

Data describing the reduction of oak trees are listed in Table 1.

Significant decrease of oak can be stated for all analyzed stand parameters. The future development of the following generation of natural forest can be estimated by the state of the natural regeneration and dynamics of height shifts of tree species located in the lower tree layer with h>130cm (Tab. 2).

There were some differences in term of vertical shifts of trees during the period of 33 years. In 2011, the Norway maple (778 N.ha') and sycamore maple (222 N.ha') represent dominant species in the lower tree layer. European ash occurs in the whole vertical profile of the natural forest. Its abundance in height category "> $130 \mathrm{~cm}$ " is 50 N.ha-1. Evaluating the other height categories of natural regeneration, listed tree species (ash and maples) represent $93 \%$ of the total number of individuals

\section{Discussion}

The tree species composition of a climax forest reflects a complex of ecological conditions of the particular site. Developmental cycle and structure of an old-growth forest formed by six tree species with different tolerance to light has some substantial features, which in general differ from the common knowledge about the developmental cycle of an old-growth forest. Oldgrowth forests with such a rich composition of tree species contributing to the spatial structure of the forest stand are very rare in the temperate zone of Europe. 
Natural forests in NNR Sitno (Danková 2012) and NNR Hrončecký Grúň (Holeksa et al. 2009, Saniga et al. 2011) belong among the most species-rich old-growth forests in the central Europe. In condition of Poland, the old-growth forest Bialowieza (Bobiec 2007, 2012) and the Jata reserve (Dobrowolska 1996, Dobrowolska, Veblen 2008) are taking place within the mentioned group.

Analysis of dynamic changes in portion of partial tree species in NNR Sitno revealed the significant continuous decrease of all stand parameters (number of individuals, basal area and volume of large wood) dealing with oak trees during the last 33 years.

Our findings correspond with the general decline of oaks in European conditions in last decades (Siwecki, Ufnalski 1998, Thomas et al. 2002, Rohner et al. 2012).

A similar situation was observed for the hornbeam however a different way of stand development was recorded for the beech. The beech abundance has decreased during last 33 years but we observed the significant increase of the beech basal area and volume of large wood. Regarding this course of stand characteristic development, we can state that beech is achieving the dominant position within the upper tree layer what is consequently connected with its intensive radial increment.

Decline of oak in the condition of natural forests was studied by Rohner et al. (2012). Authors provided a complex study of the successional change in beech-oak relationship in Swiss forests.

Mentioned process has been, according to opinion of authors, caused by synergistic impact of the structural change (i.e. tree size and stand basal area) of investigated stands and change of climate. However, the effect of stand structure on oak mortality was higher than the climate impact. Increasing oak mortality with increase of stand basal area is a plausible consequence of its lower relative competitiveness and high demand for light. Thus, in forests developing towards higher stand basal area, the ecologically important oak is increasingly outcompeted by beech, unless competition is reduced through management or disturbances. Klimaš (2009) and Tomaštík, Saniga (2011) observed the continual decrease of the oak proportion to favour beech in natural forests Kašivárová (from 84 to $23 \%$ ) and Bujanov (from 92 to $42 \%$ ). The authors suggest that the seed crops frequency and mortality of mature oak trees could be the possible reasons of recorded decrease in NNR Kašivárová. Moreover the rich seed crops of F. sylvatica can be added. If we consider a high tolerance of F. sylvatica to light, the ecological profile of this natural reserve provides ideal conditions for the establishment and subsequent growth of beech. High decrease of oak proportion recorded in NNR Kašivárová might have been also affected by the oak wilt disease (fungi Ceratocystis fagacearum /Bretz/ Hunt) that occurred around whole Slovak forests in '70s (Burkovský 1985).

Different tolerance of tree species to light conditions causes spatiotemporal variations in the beginning of natural regeneration among individual tree species. A significant irregularity in occupancy of gap areas by different tree species was observed (Yamamoto 2000, Nagel, Diaci 2006, Rozenbergar et al. 2007). Therefore the disturbance regime can be considered the main factor affecting the changes in tree species composition of natural forests (Saniga et al. 2011). In the case of the old-growth forest Sitno, we can observe a large increase of all tree species during 30 years of periodical inventory, especially with high dominance of ash and both maples in all height classes in the last measurement. The dominance of maple in all height classes of natural regeneration describes also Dobrowolska, Veblen (2008) in Jata Reserve. This confirmed findings of Saniga et al. (2011) in old-growth forest Hrončecký Grúň, where authors recorded the highest abundance of maples and ash regeneration. In spite of high numbers of maple and ash regeneration their successful outgrowing to the upper height categories was systematically retarded by ungulates browsing. The expansion of maple juveniles in recent years has been observed also in Poland, not only on optimal sites but also on the coniferous forest site types (Faliński, Pawlaczyk 1993, Kowalski 1993, Bobiec 2007).

We suggest that maples and ash will increase their proportion on the stand structure of investigated natural forest in the next decades. High abundance of natural regeneration and the dynamics of height outgrowing of mentioned species is supporting this suggestion. We assume that the oak proportion will decrease in the next decades due to the relatively low competitive ability and the higher light demand in comparison to beech. We expect successful establishment and outgrowing of oak samplings after the influence of larger scale disturbance that is able to secure higher light income for survived oak trees. According to von Lüpke (1998), the oak regenerates successfully when the light level does not fall below $15-20 \%$, and after the two years it requires at least $30-60 \%$ of full light for a successful outgrowing. Petritan et al. (2012), on the 
example of old-growth forest Runcu-Grosi, state that in the absence of any major disturbance to the canopy, it is likely without silvicultural interventions to favour oak, the dominance of beech will increase and significantly fewer oaks will be found in the next stand generation.

\section{References}

Blattný, T., ŠŤAstný, T. 1959: Prirodzené rozširenie lesných drevín na Slovensku [Natural distribution of forest tree species in Slovakia]. Bratislava: SVPL, $402 \mathrm{s.}$

BobIEc, A. 2007: The influence of gaps on tree regeneration: a case study of the mixed limehornbeam (Tilio-Carpinetum Tracz. 1962) communities in the Bialowiez a Primeval Forest. Polish Journal of Ecology, 55 (3): 441-455.

Bobiec, A. 2012: Bialowieza Primeval Forest as a remnant of culturally modified ancient forest. European Journal of Forest Research, 131 (5): 1-17.

BRANG, P. 2005: Virgin forests as a knowledge source for central European silviculture: reality or myth? Forest Snow and Landscape Research, 79: 19-32.

BuRKovsKÝ, J. 1985: Viac pozornosti hromadnému hynutiu dubov v chránených územiach [More attention to natural oak decline]. Pamiatky prírody, 1: 26-27.

DANKovÁ, L. 2012: Produkčné pomery a nekromasa pralesa Sitno [The production patterns and necromass of old-growth forest Sitno]. In: Saniga M., Kucbel S., Jaloviar P. (eds.): Pestovanie lesa v strednej Európe. Zvolen: Technická univerzita vo Zvolene, 143-152.

Diaci, J., Gyoerek, N., Gliha, J., Nagel, T.A. 2008: Response of Quercus robur L. seedlings to north-south asymmetry of light within gaps in floodplain forests of Slovenia. Annals of Forest Science, 65: 1051-1058.

Dobrowolska, D. 1996: Dynamika odnowienia jodty pospolitej (Abies alba Mill.) w zasiegu wyspowym na Podlasiu na przykładzie rezerwatu "Jata". [Dynamics of silver fir (Abies alba Mill.] regeneration in Podlasie in the Jata Reserve) SGGW, Warszawa (doctoral thesis), $133 \mathrm{~s}$.

Dobrowolska, D., Veblen, T.T. 2008: Treefallgap structure and regeneration in mixed Abies alba stands in central Poland. Forest Ecology and Management, 255: 3469-3476.

\section{Acknowledgement}

This study was supported by the Slovak Research and Development Agency, project No. APVV-0286-10.

FAliński, J.B., PAWlaczyK, P. 1993: Zarys ekologii (Outline of ecology). In: Grab zwyczajny Carpinus betulus L., Instytut Dendrologii PAN, Sorus, Poznań-Kórnik, 157-264.

Holeksa, J., Saniga, M., Szwagrzyk, J., CzerniaK, M., StaszyńsKa, K., Kapusta, P. 2009: A giant tree stand in the Western Carpathians - An exception or a relic formerly widespred mountain European forests? Forest Ecology and Management, 257: 1577-1585.

KavUljaK, A. 1942: Dejiny lesníctva a drevárstva na Slovensku [History of the forestry and timber industry in Slovakia]. Turčiansky sv. Martin, $244 \mathrm{~s}$.

KLimAš, V. 2009: Štruktúra, produkčné pomery, regeneračné procesy a textúra vybraných dubových pralesov Slovenskej republiky [Structure, production, regeneration and texture of selected oak virgin forests in Slovakia]. Dizertačná práca, TU Zvolen, $87 \mathrm{~s}$.

KorpeL, Š. 1995: Die Urwälder der Westkarpaten. Stuttgart. Gustav Fischer Verlag, 330 S.

Korpel, Š., SAniga, M. 1995: Prírode blízke pestovanie lesa [Close-nature silviculture]. Zvolen, UVVP LVH SR, $158 \mathrm{s.}$

KoWALsKI, M. 1993: The development of natural forest stands in the Białowiez a National Park. Folia Forestalia Polonica, 35: 35-48.

Leibundgut, H. 1993: Europäische Urwälder. Verlag Paul Haupt, Bern, 260 S.

LuKÁČIK, I., ĎURIŠ, M., 2012: Rastové charakteristiky dominantných druhov drevín v lesostepných spoločenstvách Krupinskej planiny a Strážovských vrchov [Growth characteristic of dominant tree species of forest steppe associations in Krupinska plateau and Strážovské Mts.]. In: SANIGA M., Kucbel S., Jaloviar P. (eds.): Pestovanie lesa v strednej Európe. Zvolen: Technická univerzita vo Zvolene, 181-191.

LukÁčik, I., Ďuriš, M., Kollâr, V. 2012: Lesostepné spoločenstvá Strážovských vrchov [Forest steppe assocciations in the Strážovské Mts.]. Acta Facultatis Forestalis Zvolen, 54 (2): 7-19. 
Meyer, P. 2005: Network of Strict Forest Reserves as reference system for close to nature forestry in Lower Saxony, Germany. Forest Snow and Landscape Research, 79: 33-44.

Nagel, T.A., DiAcI, J. 2006: Intermediate wind disturbance in an old-growth beech-fir forest in southeastern Slovenia. Canadian Journal of Forest Research, 36: 629-638.

Parviainen, J. 2005: Virgin and natural forests in the temperate zone of Europe. Forest Snow and Landscape Research, 79: 9-18.

Parviainen, J., Little, D., O’Sullivan, A., Kettunen, M., Korhonen, M. 1999: Research in Forest reserves and natural Forests in European Countries. EFI Proceedings No 16. Joensuu: European Forest Institute, 304 pp.

Petráš, R., Рajtík, J. 1991: Sústava československých objemových tabuliek dreva [Czechoslovakian timber volume tables]. Lesnicky časopis, 37: 49-56.

Petritan, A. M., Biris, I. A., Merce, O., Turcu, DO., Petritan, I. C. 2012: Structure and diversity of a natural temperate sessile oak (Quercus petraea L.) - European Beech (Fagus sylvatica L.) forest. Forest Ecology and Management, 280: 140-149.

Prodan, M. 1951: Messung der Waldbestande. Sauerlander's Verlag, Frankfurt am Main.

Rahman, MM., Frank, G., Ruprecht, H., Vacik, H. 2008: Structure of croase woody debris in Lange-Leitn Natural Forest Reserve - Austria. Journal of Forest Science, 54: 161-169.

Rohner, B., Bigler, Ch., Wunder, J., Brang, P., BugmanN, H. 2012: Fifty years of natural succession in Swiss forest reserves: changes in stand structure and mortality rates of oak and beech. Journal of Vegetation Science, 23: 892-905.

Rozenbergar, D., Mikac S., Anić I., Diaci, J. 2007: Gap regeneration patterns in relationship to light heterogeneity in two old-growth beech - fir forest reserves in South East Europe. Forestry.doi:10.1093/forestry/cpm037.

Saniga, M., Balanda, M., Kucbel, S., Jaloviar, P. 2011: Cyclic changes in tree species composition of mixed-species forest in western Carpathians: role of disturbance and tree regeneration. Polish Journal of Ecology, 59 (4): 609-708.

ScнÜтz, J.P.H. 2002: Uneven-aged silviculture: tradition and practices. Forestry, 75: 327-328

Siwecki, R., UfNalski, K. 1998: Review of oak stand decline with special reference to the role of drought in Poland. European Journal of Plant Pathology, 28: 99-112.
Smejkal, GM., Bindiu, C., Vişoiu-Smejkal, D. 1995: Banater Urwälder. Temesvar: Verlag Mirton, $198 \mathrm{~S}$.

ŠmeLKo, Š. 2000: Dendrometria [Dendrometry]. Vydavatel'stvo Technickej univerzity, Zvolen, $399 \mathrm{~s}$.

Thomas, F. M., Blank, R., Hartmann, G. 2002: Abiotic and biotic factors and their interactions as causes of oak decline in Central Europe. Forest Pathology, 32: 277-307.

TomAšтík, J., SANigA, M. 2011: Štruktúra a vel'kost' porastových medzier v NPR Bujanovská dubina [Structure and gap size in NNR Bujanovská dubina]. Acta Facultatis Forestalis Zvolen, 53 (2): 19-28.

Vacik, H., Rahman, MM., Ruprecht, H., Frank, G. 2009: Dynamics and structural changes of an oak dominated Natural Forest Reserve in Austria. Botanica Helvetica, 119: 23-29.

VON LÜPKE, B. 1998: Silvicultural methods of oak regeneration with special respect to shade tolerant mixed species. Forest Ecology and Management, 106: 19-26.

Vrška, T., Hort, L., Adam, D., Odehnalová, P., Horal, D. 2006: Developmental dynamics of virgin forest reserves in the Czech republic. Prague: Academia, $214 \mathrm{pp}$.

Yамамото, S. 2000: Forest Gap Dynamics and Tree Regeneration. Journal of Forest Research, 5: 223-229.

Zlatník, A. 1956: Fytocenologie lesa [Phytocenology of the Forest]. Lesnická Fakulta VŠZ Brno, $96 \mathrm{~s}$. 